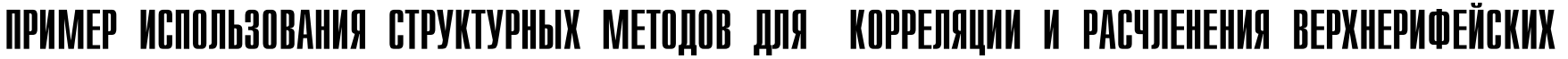 И НИКНЕПАЛЕОЗОЙСКИХ ОТЛОЖЕНИЙ СЕВЕРНОЙ ЧАСТИ ПРИПОЛЯРНГГО УРАЛА
}

\author{
И. Л. Потапов 1 , К. С. Попвасев² \\ ${ }^{1}$ Институт геологии Коми НЦ УрО РАН, Сыктывкар; ilpotapov@geo.komisc.ru \\ ${ }^{2}$ Сыктывкарский государственный университет им. Питирима Сорокина, Сыктывкар
}

В статье изложены результаты изучения макро- и микроструктурных особенностей метаморфизованных отложений, слагающих среднюю и верхнюю части верхнедокембрийского (хобеинская и мороинская свиты) и нижнюю часть палеозойского (обеизская свита) разрезов на севере Приполярного Урала. Общими структурными признаками для всех этих свит являются как наличие сланцеватости, падающей на СЗ под средними и пологими углами, так и наличие похожих друг на друга ориентировок оптических осей кварца, характерных для пород, зерна кварца которых испытывали трансляционное (дислокационное) скольжение в условиях сжатия и сдвига. Отличительными структурными признаками хобеинской и мороинской свит от обеизской свиты являются, во-первых, наличие в первых двух асимметричных складок с осевыми плоскостями СВ-падения под крутыми углами, во-вторых, наличие наблюдаемого в поляризационный микроскоп кренуляционного кливажа и в-третьих, существование в двух первых свитах ориентировок оптических осей кварца, характерных для пород, претерпевших интенсивные складчатые дефомации. Все это позволяет предложить дополнительные критерии для расчленения и корреляции рассматриваемых в данной работе метаморфических образований бассейна р. Кожим.

Ключевые слова: Приполярный Урал, докембрий, верхний рифей, нижний ордовик, структурная геология, складки, микроструктурный анализ, оптические оси кварца.

\section{AN EXAMPLE OF THE USE OF STRUCTURAL METHODS FOR THE CORRELATION AND SEPARAIION OF THE UPPER RIPHEAN AND LOWER PALEOZOIC FORMATION OF THE NORTHERN PART OF THE SUBPOLAR URALS}

\author{
I. L. Potapov'1, K. S. Popvasev² \\ ${ }^{1}$ Institute of Geology Komi SC UB RAS, Syktyvkar \\ ${ }^{2}$ Pitirim Sorokin Syktyvkar State University, Syktyvkar
}

The paper presents the results of studying the macro- and microstructural features of the metamorphic rocks average and top Low Precambrian (Hobein and Moroya suits) and the Lower part Paleozoic (Obeiz suite) sections in the North of the Subpolar Urals.

The macro and microstructural features of the rocks of the northern part of the Subpolar Urals, such as the Hobein, Moroya and Obeiz suites are studied in the article. The common structural features for all these formations are both the presence of the falling on the NW at medium and low angles, and the presence of similar orientations of the optical c-axes quartz fabric for rocks which quartz grains experienced translational (dislocation) sliding under compression and shear conditions. The distinctive structural features for the rocks of the Hobein and Moroya formations from the rocks of the Obeiz suite are, firstly, the presence of the early two asymmetric folds with axial planes of of the NE-falling at steep angles, and secondly, the presence of crenulation cleavage observed in the polarization microscope, and thirdly, the existence in these two sets of orientations of optical quartz axes characteristic of rocks that underwent intensive folded deformations. All this allows us to propose additional criteria for the dismemberment and correlation of the metamorphic formations of the Kozhim river basin.

Keywords: Subpolar Urals, Precambrian, Upper Riphean, Lower Ordovician, structural geology, folds, microstructure analysis, c-axes of quartz.

\section{Введение}

Северная часть Приполярного Урала сложена мощной толщей дислоцированных метаморфических пород, прорванных интрузиями различного состава и многочисленными жилами. Расчленение и картирование исследуемых метаморфических пород намного усложняются в связи с целым рядом особенностей, присущих таким образованиям. Эти особенности связаны с трудностью выделения в них опорных горизонтов в связи с глубокими и часто многократными преобразованиями их вещественного состава, сложностью их пликативной тектоники, глубо- кими и часто многократными преобразованиями их вещественного состава и структуры. Традиционные методы расчленения и корреляции, литологические и палеонтологические, для метаморфизованных отложений малоприменимы, и именно поэтому вопросы стратиграфии докембрия Приполярного Урала, основную часть которого слагают такие образования, являются относительно слабо разработанными [9].

Одним из широко применяющихся методов при изучении метаморфических толщ является структурный метод. Установление макро- и микроструктурных особен- 
ностей метаморфических пород и их структурной эволюции позволяет предложить дополнительные критерии для расчленения и корреляции этих образований.

\section{Методы исследования}

В работе используются данные, полученные авторами непосредственно при полевых наблюдениях в верховьях р. Кожим и по его многочисленным притокам, ручьям Бол. Каталамбию и Малая Каталамбию, р. Пеленгичей, p. Балбанъю, а также по водоразделам. Для более подробного изучения структурных особенностей пород верхнего докембрия и нижнего палеозоя использовались методы морфолого-геометрического анализа [6] плоскостных и линейных элементов пород. Дополнительно нами был проведен микроструктурный анализ, который заключался в определении в шлифах ориентировок оптических осей кварца и спайностей слюд с применением универсального четырехосного столика Федорова на поляризационном микроскопе [5, 12]. Ориентированные образцы отбирались согласно контактам пород на крыльях складок для различных разновозрастных толщ, по ориентировке слоистости, а также сланцеватости и полосчатости в метаморфизованных породах. Результаты замеров микроструктур выносились на стереографические диаграммы (нижняя полусфера, равноугольная сетка) и анализировались с использованием компьютерной программы Sereonet [13].

\section{Геология, стратиграфия}

В данной работе исследуются подразделения, относящиеся к верхнему рифею, такие как хобеинская и мороинская свиты, претерпевшие зеленосланцевый метаморфизм умеренных давлений [8]. Они рассматриваются как допалеозойское $\left(\mathrm{RF}_{3}\right)$ обрамление няртинского комплекса (рис. 1) наряду с маньхобеинской, щокурьинской и пуйвинской свитами [9]. Выше залегают саблегорская $\left(\mathrm{RF}_{3}-\mathrm{V}\right)$ и лаптопайская $(\mathrm{V})$ свиты, которые в данной работе не рассматриваются. Из нижнепалеозойского разреза нами рассмотрена обеизская свита.

Хобеинская свита $\left(\mathrm{RF}_{3} \mathrm{hb}\right)$ суммарной мощностью 700-1000 м залегает с размывом на сланцах пуйвинской свиты [8]. Отложения свиты распространены по р. Пелингичей, в бассейне руч. Еркусей и в районе горы Пон-из (рис. 1). Свита представлена светлыми зеленовато-серыми тонкополосчатыми хлорит-мусковит-альбит-кварцевыми и мусковит-альбит-кварцевыми сланцами, белыми и светло-серыми кварцитами и известковистыми кварцитопесчанниками, в подчиненном количестве встречаются темно-серые филлитовидные сланцы. В нижней части разреза присутствуют линзы и прослои конгломератов. Конгломераты по составу преимущественно кварцевые. Позднерифейский возраст хобеинской свиты устанавливается по её залеганию под охарактеризованными органическими остатками мороинской свиты [11].

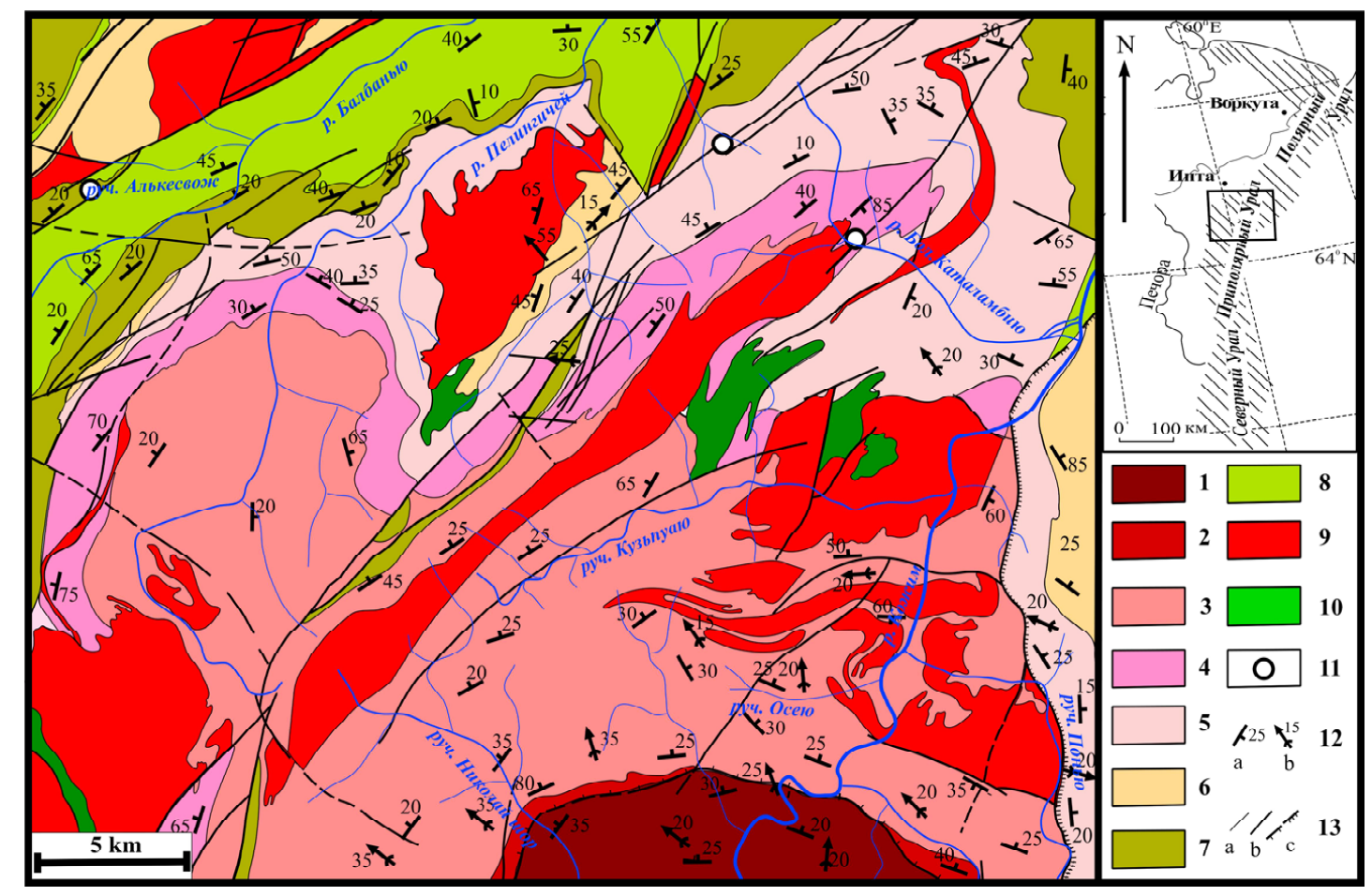

Рис. 1. Геолого-структурная схема отложений северной части Приполярного Урала (геологическая основа составлена А. М. Пыстиным): 1 - няртинский метаморфический комплекс $\left(\mathrm{PR}_{1}\right) ; 2-$ щокурьинская свита $\left(\mathrm{RF}_{1}\right.$ ?); 3 - пуйвинская свита $\left(\mathrm{RF}_{2}\right)$; 4 - хобеинская свита $\left(\mathrm{RF}_{3}\right) ; 5$ - мороинская свита $\left(\mathrm{RF}_{3}\right) ; 6$ - саблегорская свита $\left(\mathrm{RF}_{3}-\mathrm{V}\right) ; 7$ - обеизская свита $\left(\mathrm{O}_{1}\right) ; 8-$ нерасчлененные отложения нижнего палеозоя $(\mathrm{E}-\mathrm{O})$; 9 - граниты; 10 - габбро; 11 - точки отбора ориентированных проб; 12 - элементы залегания плоскостных неоднородностей: слоистости, сланцеватости, полосчатости (a) и шарниров (b); 13 - границы стратиграфических и интрузивных подразделений(a), разломы (b), надвиги (c)

Fig. 1. Geological and structural scheme of the rocks of the northern part of the Subpolar Urals (geological basis compiled by A.M. Pystin): 1 - Nyartin metamorphic complex $\left(\mathrm{PR}_{1}\right) ; 2-$ Shokurya suite $\left(\mathrm{RF}_{1}\right.$ ?); 3 - Puyva suite $\left(\mathrm{RF}_{2}\right) ; 4-$ Hobein suite $\left(\mathrm{RF}_{3}\right) ; 5-\mathrm{Moroya}_{3}$ suite $\left(\mathrm{RF}_{3}\right) ; 6$ - Sablerogorsk suite $\left(\mathrm{RF}_{3}-\mathrm{V}\right) ; 7$ - Obeiz suite $(\mathrm{O} 1) ; 8$ - undivided sediments of the Lower Paleozoic $(\mathrm{C}-\mathrm{O})$; 9 - granites; 10 - gabbro; 11 - sampling points for oriented samples; 12 - elements of occurrence of planar inhomogeneities (a), since layering, schistosity, banding, and hinges (b); 13 - boundaries of stratigraphic and intrusive subdivisions (a), faults (b), thrusts (c) 
Мороинская свита $\left(\mathrm{RF}_{3} \mathrm{mr}\right)$ залегает согласно на отложениях хобеинской свиты и характеризуется резкой изменчивостью литологического состава [11]. Свита представлена кварц-серицитовыми (филлитовидными), хлорит-серицит-кварцевыми, эпидот-альбит-кварцевыми, часто известковистыми, иногда кремнистыми тонкослоистыми серыми и зеленовато-серыми, изредка красноцветными или черноцветными сланцами, которым подчинены прослои и пачки слоистых алевролитов, «зеленых» аповулканогенных сланцев по базальтам, андезибазальтам и иногда андезитам [2]. В целом вверх по разрезу роль карбонатных пород увеличивается. Возраст мороинской свиты установлен на основании находок микрофитолитов и строматолитов на реках Бол. Каталамбию, Вангыр и ручье Еркусей [1]. На ручье Еркусей в линзе доломитов обнаружены микрофиллиты и строматолиты, позволяющие отнести данную толшу к верхнему рифею. Самые верхние слои могут относиться уже к венду [11].

Обеизская свита $\left(\mathrm{O}_{1} \mathrm{ob}\right)$. Мощность ее меняется в пределах от 150 до 1300 м, распространена в западной и осевой частях Ляпинского антиклинория [3]. Это песчаники кварцевые, олигомиктовые и полимиктовые кварцитовидные, местами косослоистые (рис. 2, d), часто светло-малиновые. Иногда в верхней половине свиты содержатся редкие прослои алевролитов и серицит-кварцевых сланцев; в нижней части - гравелиты и конгломераты; в основании - конгломераты полимиктовые базальные. Нижнеордовикский возраст свиты установлен на основании находок В. В. Маркиным в кварцитовидных песчаниках беззамковых брахиопод. Залегает обеизская свита с угловым несогласием на размытой поверхности вендских и рифейских отложений. О несогласии также свидетельствует различная степень дислоцированности ордовикских и докембрийских отложений [10].

\section{Структура, деформации}

Расчленение метаморфических толщ на структурные комплексы и этажи нередко сильно затрудняется в результате неоднократного проявления складчатых и разрывных деформаций, часто приводящих к нивелированию структурного плана различных комплексов и к маскировке разделяющих их несогласий. Поэтому в процессе сравнительного изучения дислокаций различных контактирующих метаморфических толщ важнейшее значение приобретает выявление складок различных генераций, их взаимного пространственного положения, позволяющее подойти к расшифровке и оценке степени соответствия структур рассматриваемых толщ, что необходимо для установления их соотношений $[4,6]$.

В грубообломочных породах хобеинской свиты устанавливаются элементы градационной слоистости. В относительно слабо измененных породах мороинской свиты нередко устанавливается первичная слоистость в терригенных и карбонатных образованиях и флюидальность в кислых вулканитах, метаморфическая полосчатость в слюдистых мраморах свиты выражается в чередовании полос с различным содержанием слюд, или обогащенных и обедненных кварцевым материалом, или прослоев с различной окраской или плотностью [9]. Сланцеватость упомянутых свит выражается в ориентированном распределении чешуйчатых минералов, в данном случае хлорита и мусковита. В породах обеизской свиты слоистость диагностируется достаточно уверенно: по переслаиванию разнозернистых терригенных пород, по ритмичности, по наличию тонких слойков карбонатных или кварцитовых образований, в некоторых случаях по ориентировке галек в грубообломочных отложениях и другим признакам.

Складчатость хобеинской свиты изучена нами в среднем течении р. Бол. Каталамбию на северо-восточном
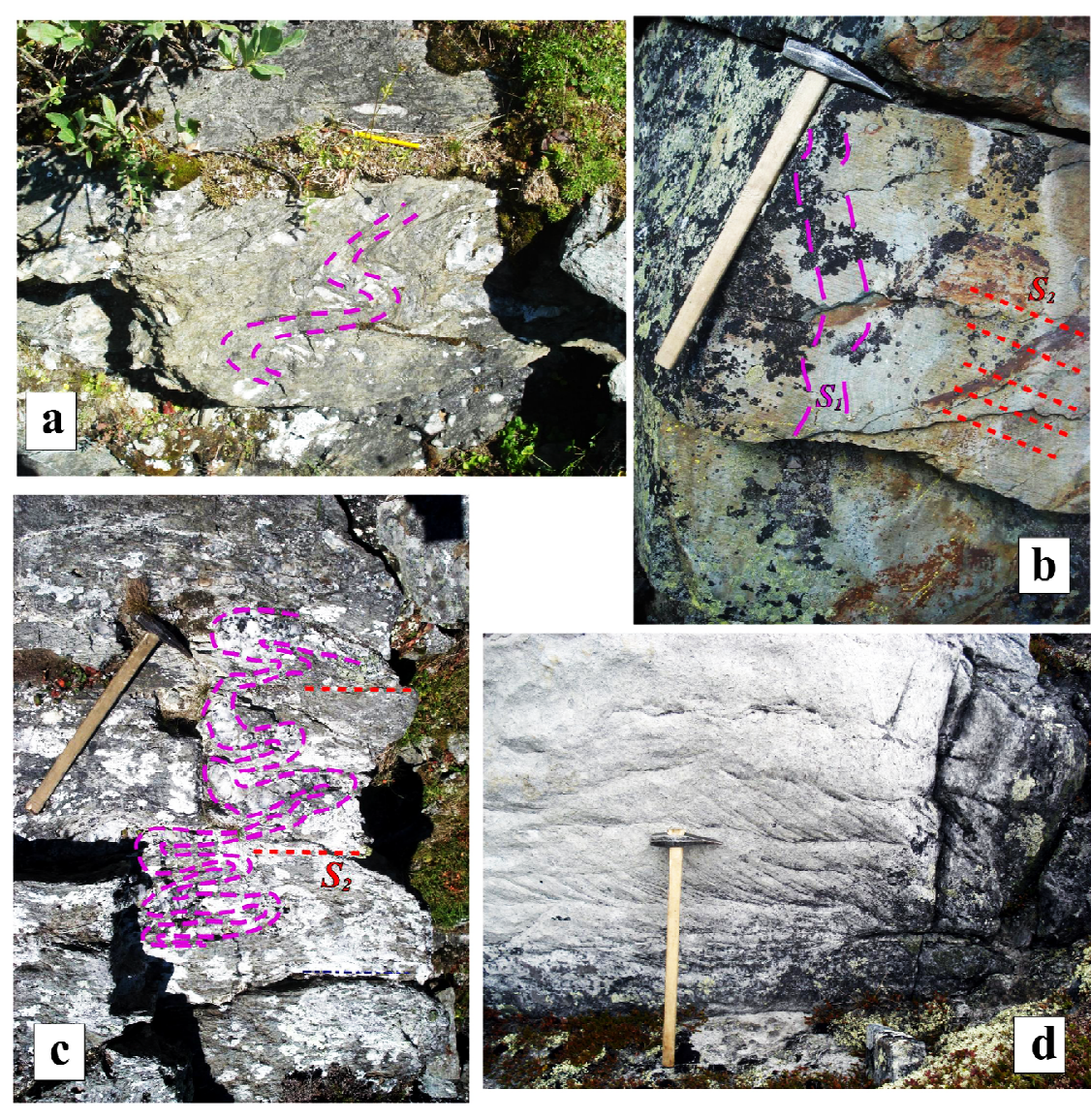

Рис. 2. Фото обнажений: a - фрагмент асимметричной складки в сланцах мороинской свиты; b - фрагмент крутопадающего короткого крыла асимметричной складки в полосчатых кварцитах хобеинской свиты, которое сечется поздней сланцеватостью $\mathrm{S}_{2}$; с - смятая в концентрические складки кварцевая жила в сланцах мороинской свиты; d - косая слоистость в кварцит-песчаниках обеизской свиты

Fig. 2. Photographs of outcrops: a - a fragment of an asymmetrical fold in the shale of the Moroya suite $; b$ - fragment of a steeply dipping short wing of an asymmetric fold in the banded quartzites of Hobein suite, which is cut by the late schistosity of $\mathrm{S}_{2} ; \mathrm{c}-$ a quartz vein crumpled into concentric folds in the shale of Moroya suite; $\mathrm{d}-$ oblique lamination in the quartzite sandstones of Obeiz suite 
выклинивании Хаталамба-Лапчинского гранитного массива. Фрагменты складок мороинской свиты были описаны на руч. Понью, где отмечены выходы кварц-серицитовых сланцев.

В наблюдаемых отложениях хобеинской и мороинской свит диагностируются две системы складок. Ранние складки асимметричные, подобные, закрытые (рис. 2, а), иногда сжатые, по осевым плоскостям развивается кливаж с крутым падением на север и северо-восток, шарниры погружаются на восток под углами от 15 до $25^{\circ}$. Короткие крылья субвертикальны, падают на северо-запад и юго-запад, секутся поздней сланцеватостью, падающей на северо-запад, реже на юго-восток, под углами от 10 до $50^{\circ}$. Данные складки аналогичны асимметричным складкам, встреченным в нижележащих отложениях $[2,7]$. Поздние складки в основном лежачие, концентрические, чаще открытые, но встречаются и сжатые, развиваются по крутопадающим крыльям и осевым поверхностям ранних складок (рис. 2, b). Параллельно осевым плоскостям поздних складок развивается поздняя сланцеватость-кливаж осевой плоскости (рис. 2, с).

В кварцитах хобеинской свиты видимые ранние складки практически не наблюдаются, поскольку имеет место достаточно слабая обнаженность пород. В основном встречаются осыпи и курумники, реже моноклинально залегающие рассланцованые отложения. Однако по характеру полосчатости, предположительно параллельной слоистости, можно восстановить элементы ранних складок. Там, где падение более крутое, поздняя сланцеватость сечет раннюю полосчатость (рис. 2, с) параллельно осевым плоскостям пологих или открытых асимметричных концентрических складок, то есть, можно сказать, что сланцеватость представляет собой кливаж осевой плоскости. Там, где слоистость падает полого, поздняя сланцеватость субпараллельна слоистости. Падает слоистость на северо-восток и на юго-запад под крутыми и средними углами, плоскости поздней сланцеватости - на запад и северо-запад под пологими и средними углами.

В сланцах мороинской свиты ранние асимметричные складки наблюдаются в достаточной степени хорошо (рис. 2, а). Данные подобные складки главным образом закрытые или сжатые, в замках иногда наблюдаются седловидные кварцевые жилы, которые встречаются и в нижележащих свитах $[2,7]$. Плоскости поздней сланцеватости, скорее всего, так же, как и для хобеинской свиты, представляют собой кливаж осевой плоскости. Они параллельны осевым плоскостям поздних концентрических складок, падающих на северо-запад под углами от 10 до $40^{\circ}$, образованным по крыльям ранних складок, иногда по ранним кварцевым жилам (рис. 2, с).

Обеизская свита изучалась на г. Еркусей и по берегам руч. Алькесвож. Здесь отмечаются выходы переслаивающихся косослоистых светло-серых песчаников (рис. 2, d) и серицит-кварцевых сланцев, в которых сланцеватость и совпадающая с ней слоистость обусловлены моноклинальным залеганием плоскостных элементов. Слоистость полого падает на запад под углами от 15 до $55^{\circ}$. Сланцеватость падает на северо-запад под углами от 45 до $70^{\circ}$.

\section{Микроструктурный анализ}

Для более точного установления и сравнения структурных особенностей стратифицированных пород докембрия Приполярного Урала нами дополнительно был проведен микроструктурный анализ. Рассмотренные выше макроструктурные особенности учитывались при выборе ориентировки каждого образца. Для уточнения ориентировки петроструктурных осей и плоскостей скольжения предварительно нами были проведены замеры ориентировок спайностей хлорита и мусковита для каждого из образцов. При этом выяснялось их соответствие ориентировкам плоскостных и линейных структурных элементов, таких как падение сланцеватости, полосчатости, слоистости, погружение шарниров. Диаграммы оптических осей кварца строились перпендикулярно плоскости скольжения S (предположительно параллельной сланцеватости) и оси удлинения L.

Для микроструктурного анализа хобеинской свиты нами взят образец НР-31-15-3 из кварцитов, точка отбора (рис. 1) расположена на правом берегу р. Большая Каталамбию, напротив устья левого безымянного притока, впадающего выше руч. Санашор. Распределение оптических осей кварца в породах мороинской свиты изучалось в мусковитхлорит-альбит-кварцевых сланцах, образец НР-52-15 был взят на руч. Малая Каталамбию. Для проведения микроструктурного анализа пород обеизской свиты и сопоставления ее с рассмотренными выше стратиграфическими подразделениями докембрия из серицит-кварцевых сланцев отобран ориентированный образец НР-43-15 на левом борту руч. Алькесвож, в 940 м ниже по течению от устья первого левого притока.

На микроуровне также можно наблюдать сочетание различных этапов деформации. Так, на микрофотографии (рис. 3, a, b) можно увидеть, как в кварцитах хобеинской свиты поздняя сланцеватость пересекает слоистость и раннюю сланцеватость, то есть формируется кренуляционная сланцеватость (кливаж плойчатости). На микрофотографиях шлифа из сланцев мороинской свиты (рис. 3, с) видно формирование такого типа сланцеватости, где микроскладки образованы по слюдам, фиксирующим раннюю сланцеватость $\mathrm{S}_{1}$, а поздняя сланцеватость $\mathrm{S}_{2}$ параллельна осевым плоскостям микроскладок (сланцеватость-кливаж осевой плоскости).

В образце из обеизской свиты ранние структуры отсутствуют, из поздних четко видно присутствие структур переотложения или растворения под давлением, таких как кливаж, бороды нарастания и тени давления при перекристаллизации порфирокласт кварца (рис. 3, d). Известно, что такие структуры главным образом формируются при наличии флюида и низкой скорости деформации в низкотемпературных условиях [4].

По данным замеров для с-осей кварца определены по два различающихся по характеру типа распределений узоров на сферических диаграммах оптических осей кварца (рис. 4). Один тип распределений оптических осей кварца (рис. $4, \mathrm{~b}, \mathrm{~d}$, e) характерен для всех образцов, в том числе и обеизской свиты, характеризуется двумя перекрестными поясами по большим кругам, примерно под прямым углом один к другому, и максимумами, один из которых сконцентрирован вблизи оси удлинения, другие - по краям диаграммы, примерно $45^{\circ}$ к плоскости скольжения, параллельной поздней сланцеватости $\mathrm{S}_{2}$. Ориентировка объясняется дифференциальными скольжениями субзерен кварца в плоскости сланцеватости $[11,13]$, но в разных зернах в различных направлениях: или по призме в направлении $c$, или по ромбоэдру в направлении $[\mathrm{r}: \mathrm{m}]$ параллельно $a$.

Для образцов хобеинской и мороинской свит встречается также другой тип распределения оптических осей 

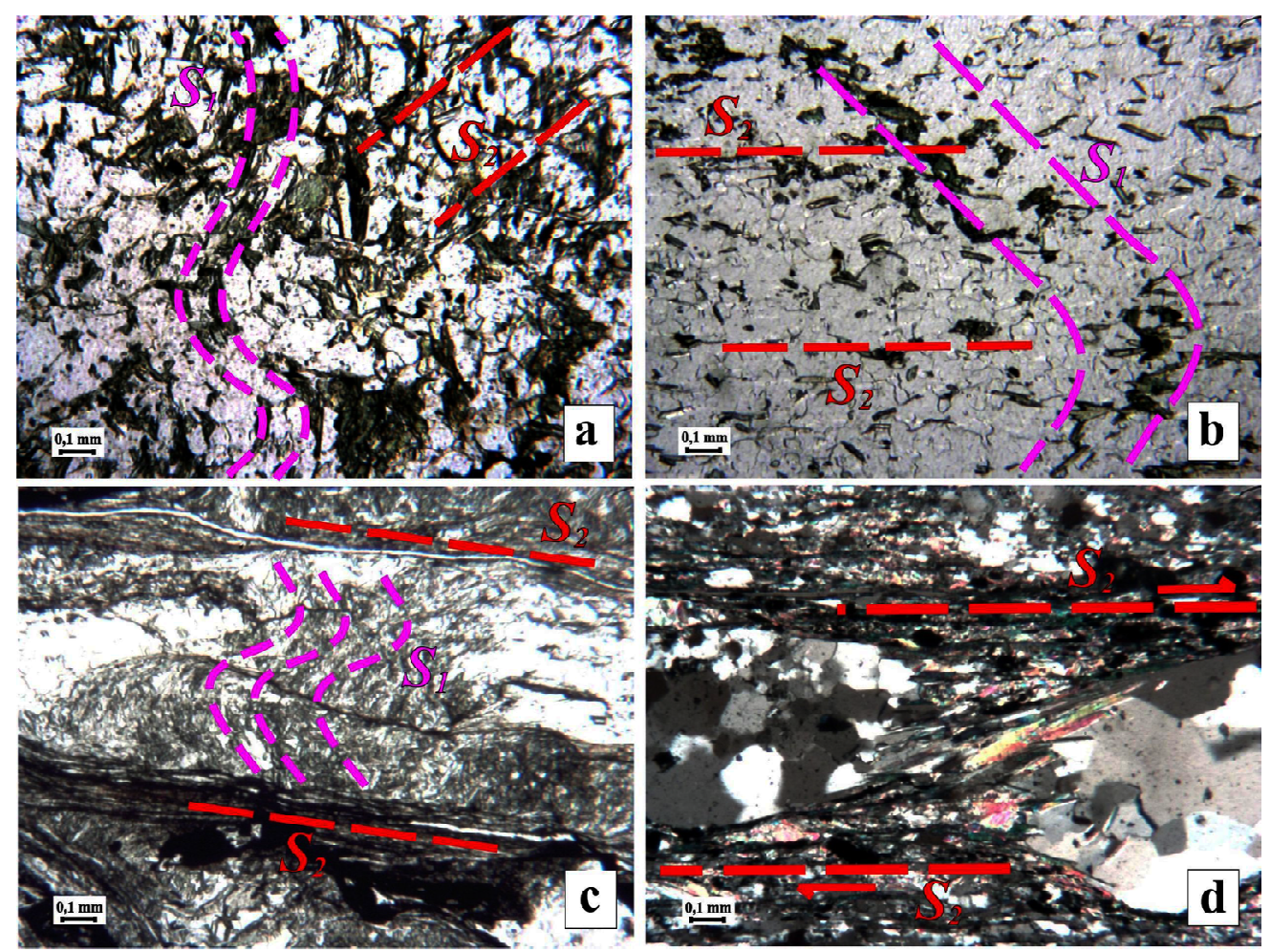

Рис. 3. Микрофотографии шлифов: $\mathrm{a}, \mathrm{b}$ - образец из кварцита хобеинской свиты, ранняя слоистость $\left(\mathrm{S}_{1}\right)$ сечется поздней сланцеватостью $\left(\mathrm{S}_{2}\right)$; с - кренуляционный кливаж в слюдистом сланце мороинской свиты, ранняя сланцеватость образует микроскладки; $\mathrm{d}$ - серицит-кварцевый сланец обеизской свиты, между кливажными доменами в микролитонах - кварцевые порфирокласты, в тени давления которых кристаллизуются кристаллы кварца и мусковита. На f, b и с микрофотографии сделаны в проходящем свете, на d - николи скрещены

Fig. 3. Microphotographs of thin sections: $a, b-$ sample from the quartzite of Hobein suite, early stratification $\left(S_{1}\right)$ is cut by late schistosity $\left(\mathrm{S}_{2}\right) ; \mathrm{c}$ - crenulation cleavage in the mica schist of Moroya suite, early shale forms microfolds; $\mathrm{d}$ - sericite-quartz slate of Obeiz suite, between the cleavage domains in microlitons quartz porphyroclasts, in the shadow pressure of which crystals of quartz and muscovite crystallize. At $\mathrm{f}, \mathrm{b}$ and $\mathrm{c}$, the microphotographs are made in transmitted light, on $\mathrm{d}-$ nikoli are crossed

кварца на сферических диаграммах (рис. 4, f, с ), который не встречен в образце обеизской свиты. Распределение представлено в виде двух поясов по малым кругам, перпендикулярным оси вращения, и нескольких максимумов, лежащих в этих поясах. Аналогичная ориентировка оптических осей кварца наблюдается в породах пуйвинской свиты [7], подстилающей хобеинскую свиту. Такое распределение оптических осей на сферических диаграммах объясняется межзерновыми вращательными движениями вокруг этой оси [11]; максимумы объясняются дифференциальными скольжениями в породе по плоскости скольжения S, а в зернах кварца - по плоскостям ромбоэдра (1011) в направлении [r: z].

\section{Обсуждение}

Исходя из анализа приведенных выше данных по микро- и макроструктурам, нужно отметить, что в истории развития хобеинской и мороинской свит имели место как минимум два деформационных этапа, в отличие от обеизской свиты, где четко различим один этап. Одним из отличительных структурных признаков для первых двух свит является наличие асимметричных складок, аналогичных складкам в пуйвинской свите [7], с крутопадающими на северо-запад осевыми плоскостями и полого погружающимися на восток шарнирами, сформированными по слоистости, полосчатости и параллельной им кристалли- зационной сланцеватости на раннем этапе деформации. Еще одним отличительным признаком для упомянутых свит является наличие наблюдаемого непосредственно и в поляризационном микроскопе кренуляционного кливажа, являющегося результатом воздействия поздней сланцеватости на ранние сланцеватость или полосчатость, что в сланцах обеизской свиты не обнаруживается.

Что касается распределения оптических осей кварца в породах хобеинской и мороинской свит, то существуют характерные распределения оптических осей кварца на сферических диаграммах в виде двух поясов по перпендикулярным оси вращения малым кругам. Такие распределения оптических осей кварца не характерны для пород обеизской свиты. Данное распределение можно объяснить тем, что зерна кварца фрагментировались и далее происходило вращение и рекристаллизация субзерен соответственно с переориентировкой с-осей кварца, при средних температурах $\left(400-600^{\circ} \mathrm{C}\right)[4,15,16]$. В некоторых случаях имели место кристаллизация или переориентировка слюд параллельно осевым поверхностям складок. Таким образом, структурные и микроструктурные данные говорят о том, что отложения хобеинской и мороинской свит на ранних стадиях становления испытывали интенсивные складчатые деформации.

Общим для всех трех свит является наличие сланцеватости северо-западного и западного падения под сред- 


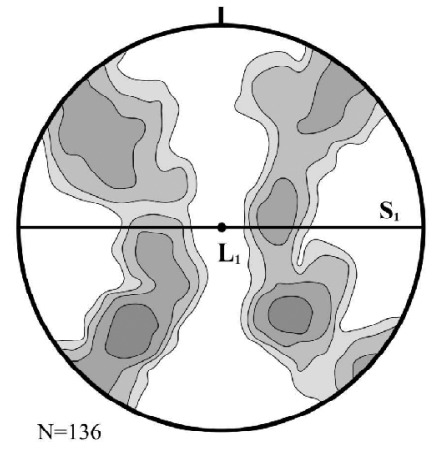

$\mathbf{a}$

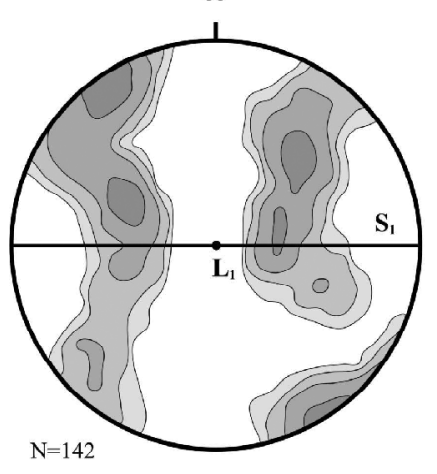

c

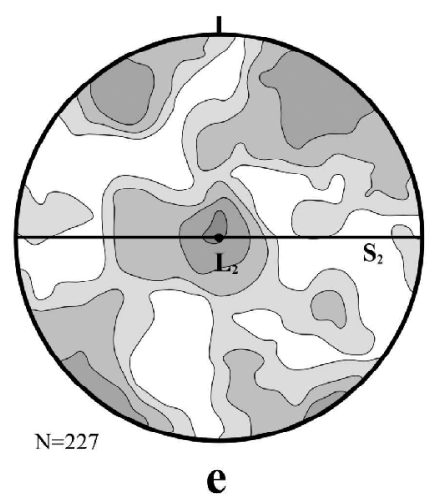

$\mathbf{e}$

Рис. 4. Сферические диаграммы ориентировок оптических осей кварца для хобеинской $(\mathrm{a}, \mathrm{b})$, мороинской $(\mathrm{c}, \mathrm{d})$ и обеизской (e) свит. S - плоскость скольжения, L - направление скольжения (линейность). Равноугольная сетка, нижняя полусфера. Изолинии плотности оптических осей кварца даны с шагом

$$
1-2-4-8 \%
$$

Fig. 4. Spherical diagrams of orientations of quartz c-axes for Hobeya (a, b), Morya (c, d) and Obeiz (e) suites. S - slip plane, L - slip direction (linearity). Equal grid, the bottom hemisphere. The isolines of the density of optical quartz axes are given in steps of $1-2-4-8 \%$

ними и крутыми углами; в рассматриваемых верхнерифейских породах она сечет ранние структуры. На микроуровне это выражается в концентрации слюд и других минералов в протяженных зонах (кливажных доменах). При этом в отложениях хобеинской и мороинской свит по ранее сформировавшимся крыльям, по сланцеватости и прочему образовывались концентрические лежачие складки с развитием кливажа параллельно осевым плоскостям, на микроуровне наблюдается кливаж плойчатости. В породах обеизской свиты помимо кливажа наблюдаются структуры растворения под давлением. Одинаковые ориентировки оптических осей кварца во всех рассмотренных в данной работе отложениях показывают распределение, получаемое при трансляционном (дислокационном) скольжении в условиях сжатия и сдвига. Выявленные микроструктуры характерны для условий низкой скорости деформации в низкотемпературных условиях и при наличии флюида $[4,15,65]$. Все это в совокупности говорит о том, что на рассматриваемые в данной работе отложения оказывали влияние одинаковые деформации сжатия-сдвига, скорее всего связанные с формированием уралид.

\section{Заключение}

Предложенные в данной работе методы морфологогеометрического анализа и микроструктурного анализа оптических осей кварца позволяют предложить дополнительные способы определения принадлежности отложений к различным структурным этажам. Таким образом, уточнены макро- и микроструктурные особенности отложений хобеинской, мороинской и обеизской свит, их структурная эволюция, а также предложены дополнительные критерии для расчленения и корреляции верхнерифейских и нижнепалеозойских метаморфических образований бассейна р. Кожим.

Исследования проведены в рамках НИР ИГ Коми НЦ УрО РАН ГР № АААA-А17-117121270035-О и при финансовой поддержке Программы фундаментальных исследований РАH № 18-5-5-19.

\section{Литература}

1. Белякова Л. Т. Геосинклинальный рифей севера Урала: Автореф. канд. дис. М., 1972. 26 с.

2. Глубинное строение Тимано-Североуральского региона / А. М. Пыстин, В. Л. Андреичев, О. В. Удоратина и др. Сыктывкар: Геопринт, 2011. 261 с.

3. Государственная геологическая карта Российской Федерации. Масштаб 1:1000000 новая серия). Лист Q-40, 41 - Воркута. Объяснительная записка / О. А Кондиайн и др. СПб.: Изд-во СПб картофабрики ВСЕГЕИ, 2001. 342 c. +8 вкл.

4. Кирмасов А. Б. Основы структурного анализа. М.: Научный мир, 2011. 368 с.

5. Лукин Л. И., Чернышев В. Ф., Кушнарев И. П. Микроструктурный анализ. М: Наука, 1965. 123 с.

6. Методы структурного анализа полиметаморфических комплексов / А. И. Мельников, Е. П. Васильев, Л. 3. Резницкий и др.; под ред. А. И. Сизых. М.: Интермет Инжениринг, 2001. 160 с.

7. Потапов И. Л., Попвасев К. С. Структурная эволюция докембрийских пород северной части Приполярного Урала // Вестник Института геологии Коми НЦ УрО РАН, 2017. № 10. С. 9-20.

8. Пыстин А. М. Карта метаморфизма Приполярного и южной части Полярного Урала. Сыктывкар: Коми НЦ УрО РАН, 1991. 20 с. (Научные доклады).

9. Пыстин А. М. Полиметаморфические комплексы западного склона Урала. СПб.: Наука, 1994. 208 с.

10. Пыстина Ю. И. Минералогическая стратиграфия метаморфических образований Приполярного Урала. Екатеринбург: УрО РАН, 1997. 124 с.

11. Пыстина Ю. И., Пыстин А. М. Цирконовая летопись уральского докембрия. Екатеринбург, УрО РАН, 2002. 168 с.

12. Родысин А. И. Микроструктурный анализ кварца. Томск: Изд. ТГУ, 1994. 217 с.

13. Cardozo N., Allmendinger R.W. Spherical projections with OSXStereonet: Computers \& Geosciences, v. 51, 2013. P. 193-205. 
14. Hunter N. J. R., Weinberg R. F., Wilson C. J. L., Law $R$. D. A new technique for quantifying symmetry and opening angles in quartz c-axis polefigures: Implications for interpreting the kinematic and thermal properties of rocks // Jour. Struct. Geol. 2018. Vol. 112. P. 1-6. https://doi.org/10.1016/ j.jsg.2018.04.006

15. Law R. D. Deformation thermometry based on quartz c-axis fabrics and recrystallization microstructures: A review // Jour. Struct. Geol. 2014. Vol. 66. P. 129-161. https://doi.org/ 10.1016/j.jsg.2014.05.023

16. Passchier C. W., Trouw R. A. J. Microtectonics. Springer Science \& Business Media, 2005. 366 p.

\section{References}

1. Belyakova L. T. Geosinklinalnyy rifey severa Urala (Geosynclinal Riphean of the north of the Urals: Abstract of thesis. Cand. Dis. Moscow, 1972, 26 p.

2. Glubinnoye stroyeniye Timano-Severoural'skogo regiona (The deep structure in the Timan-Northern Ural region). A. M. Pystin. V.L. Andreychev, O.V. Udoratina, etc. Syktyvkar: Geoprint, 2011, 261 p.

3. Gosudarstvennaya geologicheskaya karta Rossiyskoy Federatsii. Masshtab 1:1000000 novaya seriya). List Q-40, 41 Vorkuta. Obyasnitelnaya zapiska. (State Geological Map of the Russian Federation. Scale 1: 1000000 new series). Sheet Q-40, 41 - Vorkuta. Explanatory letter. Kondiain, O. A and others. St. Petersburg: Publishing house of St. Petersburg pottery factory VSEGEI, 2001, 342 p. +8 inc.

4. Kirmasov A. B. Osnovy strukturnogo analiza (Fundamentals of structural analysis). Moscow: The scientific world, 2011, $368 \mathrm{p}$.

5. Lukin L. I., Chernyshev V. F., Kushnarev I. P. Mikrostrukturnyy analiz (Microstructural analysis). Moscow: Nauka, 1965, $123 \mathrm{p}$.

6. Metody strukturnogo analiza polimetamorficheskikh kompleksov (Methods of structural analysis of polymetamorphic complexes). Melnikov, E.P. Vasiliev, L.Z. Reznitsky and others. Ed. A.I. Sizykh, Moscow: Intermet Engineering, 2001, 160 p.
7. Potapov I. L., Popvasev K. S. Strukturnaya evolyutsiya dokembriyskikh porod severnoy chasti Pripolyarnogo Urala (Structural evolution of the precambrian rocks of the northern part of the subpolar urals) Vestnik of Institute of geology Komi SC UB RAS, Syktyvkar: Geoprint, 2017, No. 10, pp. 9-20.

8. Pystin A. M. Karta metamorfizma Pripolyarnogo $i$ yuzhnoy chasti Polyarnogo Urala (Map of metamorphism of the Circumpolar and southern part of the Polar Urals.) A series of preprints «Scientific Reports». Syktyvkar: Komi SC UB RAS, 1991, 20 pp.

9. Pystin A. M. Polimetamorficheskiye kompleksy zapadnogo sklona Urala (Polymetamorphic complexes of the western slope of the Urals). St. Petersburg: Nauka, 1994, 208 pp.

10. Pystina Yu. I. Mineralogicheskaya stratigrafiya metamorficheskikh obrazovaniy Pripolyarnogo Urala (Mineralogical stratigraphy of metamorphic formations of the Subpolar Urals). Ekaterinburg: UB RAS, 1997, 124 p.

11. Pystina Yu. I., Pystin A. M. Tsirkonovaya letopis uralskogo dokembriya (Zircon history for Ural Precambrian). Ekaterinburg, UB RAS, 2002, 168 p.

12. Rodygin A. I. Mikrostrukturnyy analiz kvartsa (Microstructural analysis of quartz). Tomsk: TSU, 1994, 217 p.

13. Cardozo N., Allmendinger R.W. Spherical projections with OSXStereonet: Computers \& Geosciences, v. 51, 2013, pp. 193-205.

14. Hunter N. J. R., Weinberg R. F., Wilson C. J. L., Law R. D. A new technique for quantifying symmetry and opening angles in quartz c-axis polefigures: Implications for interpreting the kinematic and thermal properties of rocks. Jour. Struct. Geol. 2018, V. 112, pp. 1-6. https://doi.org/10.1016/ j.jsg.2018.04.006

15. Law R. D. Deformation thermometry based on quartz c-axis fabrics and recrystallization microstructures: A review. Jour. Struct. Geol. 2014, V. 66, pp. 129-161. https://doi.org/ 10.1016/i.jsg.2014.05.023

16. Passchier C. W., Trouw R. A. J. Microtectonics. Springer Science \& Business Media, 2005, 366 p. 